\section{Summary}

The value of the anti-inflammatory and immunosuppressant actions of corticosteroids in the treatment of certain cardiac diseases is discussed. Rheumatic pancarditis, virus pericarditis and myocarditis, and the post-pericardiotomy syndrome may respond favourably, and the treatment may sometimes obviate the need for artificial pacing in complete heart-block. The use of corticosteroids in intractable cardiac oedema is also discussed.

\section{REFERENCES}

Aber, C. P., and Wyn Jones, E. (1960). Brit. Heart F., 22, 723

Bayli. (1965). Ibid., 27, 916.

Bayliss, R. I. S. (1959)., Proc. roy. Soc. Med., 52, 929.

Bengsston, E., and Orndahl, G. (1954). Acta med. scand., 149, 381.

Burch, G. E., and De Pasquale, N. P. (1965). Viral Myocarditis in Cardiomyopathics, edited by G. E. W. Wolstenholme and M. O'Connor, p. 376. Churchill, London.

Bywaters, E. G. L., and Thomas, G. T. (1961). Brit. med. 7., 1, 1628.

Cámara, A. A., and Schemm, F. R. (1955). Circulation, 11, 702 .

Caramelli, Z., and Tellini, R. R. (1960). Amer. F. Cardiol., 5, 263.

Cattan, R., and Vesin, P. (1956). Sem. Hôp. Paris, 32, 712 .

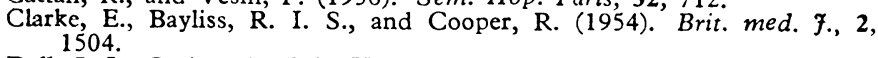

Dall, J. L. C. (1964). Brit. Heart F., 26, 537.

and Buchanan, J. (1962). Lancet, 2, 8.

Davies, M. J. (1966). Communication to the Association of Physicians.

Dingman, J. F., Finkenstaedt, J. T., Laidlaw, J. C., Renold, A. E., Jenkins, D., Merrill, J. P., and Thorn, G. W. (1958). Metabolism, 7, 608.

Dresdale, D. T., Greene, M. A.. and, Guzman, S. V. (1958). Amer. Heart F., 55, 851.

Ehrenfeld, E. N., Gery, I., and Davies, A. M. (1961). Lancet, 1, 1138. Friedberg, C. K., Kahn, M., Scheuer, J., Bleifer, S., and Dack, S.
(1960). f. Amer. med. Ass., 172, 1146.
Gutner, L. B., Moses, J. B., Dann, S., and Kupperman, H. S. (1957). Amer. F. med. Sci., 234, 281.

Hatfield, C. B., and Shuster, S. (1959). F. Endocr., 18, 262.

Haymaker, W., and Kernohan, J. W. (1949). Medicine (Baltimore), 28, 59.

Heidorn, G. H., and Schemm, F. R. (1955). Amer. 7. med. Sci., 229, 621 . Houser, H. B., Clark, E. J., and Stolzer, B. L. (1954). Amer. f. Med.,
16, 168 .

Illingworth, R. S., Lorber, J., Holt, K. S., and Rendle-Short, J. (1957). Lancet, 2, 653 .

Lasché, E. M., and Durant, T. M. (1957). Amer. ₹. med. Sci., 233, 80. Ledingham, J. G. G., and Bayliss, R. I. S. (1965a). Clin. Pharmacol. Ther., 6, 474.

Lorenzen, I., and (1965). Brit. med. 7., 2, 732.

Lorenzen, I., and Videbæk, Aa. (1965). Lancet, 2, 558.

Medical Research Council and American Heart Association (1955). Brit. med. $7 ., 1,555$.

Mickeron (1965). Ibid., 2, 607.

Mickerson, J. N., and Swale, J. (1959). Brit. med. F., 1, 876.

Pay, B. W., and Waverley, A. (1961). Ibid., 2, 139.

Pechet, M. M., Bowers, B., and Bartter, F. C. (1959). 7. clin. Invest., 38, 681,691 .

Phelps, M. D., and Lindsay, J. D. (1957). New Engl. 7. Med., 256, 204.

Prinzmetal, M., and Kennamer, R. (1954). F. Amer. med. Ass., 154, 1049 .

Raisz, L. G., McNeely, W. F., Saxon, L., and Rosenbaum, J. D. (1957). f. clin. Invest., 36, 767 .

Riemer, A. D. (1956). Bull. Fohns Hopk. Hosp., 98, 445.

Roberts, W. C., and Fox, S. M. (1965). Circulation, 32, 342.

Robinson, J., and Brigden, W. (1963). Brit. med. 7., 2, 706.

Sherlock, S., Senewiratne, B., Scott, A., and Walker, J. G. (1966). Lancet, $1,1049$.

Slater, J. D. H. (1961). Ann. rheum. Dis., 20, 173.

Swan, W. G. A. (1960). Brit. Heart f., 22, 651 .

Thomas, G. T. (1961). Brit. med. F., 1, 1635.

van der Geld, H. (1964). Lancet, 2, 617 .

Verel, D., Mazurkie, S. J., and Rahman, F. (1963). Brit. Heart. F., 25, 709 .

Wilson, M. G. (1960). Advanc. Pediat., 11, 243.

Zoob, M., and Smith, K. S. (1963). Brit. med. F., 2, 1149.

\title{
Concentration of Chloramphenicol in the Urine and Blood in Relation to Renal Function
}

\author{
A. A. LINDBERG,* M.D.; L.H.: son NILSSON, + M.D. ; H. BUCHT, $\dagger$, M.D. ; L. O. KALLINGS,* M.D.
}

Brit. med. F., 1966, 2, 724-728

Because of the occurrence of multiresistant bacterial strains in chronic infections of the urinary tract the physician is aften faced with the necessity of choosing a therapeutic agent differing from those normally resorted to in the first instance. According to in vitro determinations, these multiresistant strains are often relatively sensitive to chloramphenicol. Treatment is of ten complicated by the occurrence of anatomical changes in the kidneys and the urinary tract, and by impairment of the renal function.

Most antibiotics are eliminated from the body by the kidneys, and so the concentration of such substances in the blood and urine is dependent on the renal function. If this function is impaired an antibiotic and its metabolites may be retained in the blood in concentrations which may have toxic effects (Erlanson and Lundgren, 1964). When giving antibiotic therapy, therefore, the renal function should be taken into consideration, with regard to the risk of overdose as well as the difficulty of attaining a sufficient concentration in the urine. Kunin and Finland (1959) discussed the connexion between renal function and the excretion of various antibiotics. Principally, they found that if the concentration of the substance in the blood and the volume of urine are constant, then the concentration of the substance in the urine is directly

\footnotetext{
* From the National Bacteriological Laboratory, Stockholm.
}

† From the Renal Clinic, St. Eriks Hospital, Stockholm. proportional to the clearance of the substance and to the renal function. In treatment of the urinary tract, therefore, relatively high concentrations in the urine are attained if the substance is excreted rapidly, even if the renal function of the patient is much impaired. On the other hand, antibiotics with low clearance values do not give effective urinary concentrations even in patients with good renal function, provided the serum concentrations of the substances are not raised very much. When estimating the renal function, determination of nonprotein-nitrogen and serum creatinine is often insufficient; considerable variation in the glomerular filtration may be found when these values are normal.

At the Renal Clinic of St. Eriks Sjukhus, Stockholm, we believe we have found an unsatisfactory correlation between the determination of the sensitivity of the bacterial strains in vitro and the results of chloramphenicol therapy. On reading the published reports of treatment with chloramphenicol in infections of the urinary tract we found varying results. Not unexpectedly, these were better when treating acute infections of the urinary tract than in the treatment of chronic cases (Chittenden et al., 1949 ; Hewitt and Williams, 1950 ; Turck et al., 1962).

Högman and Tillegård (1954) studied the parallelism between bacterial sensitivity in vitro and the clinical therapeutic results obtained with various antibiotics in the treatment of infections of the urinary tract. The parallelism for sulphanilamide, 
penicillin, streptomycin, aureomycin, and terramycin was very good, while for chloramphenicol it was not so good.

Previous studies have not taken the renal function into consideration when evaluating the result of chloramphenicol therapy. The present study was carried out in order to see whether the less satisfactory therapeutical results might, at least in part, be explained by low urine concentrations in states of impaired renal function. The concentration of chloramphenicol and its metabolites was measured in the blood and the urine, and was correlated with the degree of impairment of renal function.

\section{Pharmacology of Chloramphenicol}

Crystalline chloramphenicol is resorbed rapidly and almost completely from the gastro-intestinal tract (Glazko et al., 1949 ; Schück et al., 1959). Maximal values in the blood are reached two to four hours after oral administration, and 75 to $90 \%$ is excreted in the urine within 24 hours (Ley et al., 1948 ; Chittenden et al., 1949 ; Glazko et al., 1949). Less than $3 \%$ of administered chloramphenicol is excreted via the gall-bladder (Glazko et al., 1949). The maximum concentration and speed of elimination are proportional to the dose administered (Glazko et al., 1949; Ley et al., 1948 ; Hewitt and Williams, 1950; Welch and Lewis, 1951). Circulating chloramphenicol is rapidly conjugated in the liver to a monoglucuronide, which is bacteriologically inactive. About $60 \%$ of active chloramphenicol is bound to plasma proteins. Of the chloramphenicol excreted in the urine, only 5 to $15 \%$ of the dose administered is in the form of active chloramphenicol, the remainder consisting almost entirely of the inactive glucuronide (Chittenden et al., 1949 ; Glazko et al., 1949). Active chloramphenicol is cleared by glomerular filtration. In normal individuals this has been estimated at 22 to $24 \mathrm{ml} . /$ minute (Glazko et al., 1949 ; Schück et al., 1959). The administration of a tubulus-blocking agent, probenecid, does not influence this clearance (Boger et al., 1951). The inactive conjugated part is cleared by the tubuli, the rate in healthy individuals being $340 \mathrm{ml} . /$ minute (Glazko et al., 1949; Schück et al., 1959). The importance of the renal function for the concentration of chloramphenicol in the blood was studied by Kunin et al. (1959). They found that the concentration of active chloramphenicol in the blood was little influenced by the renal function, although the metabolites were retained if the function was impaired.

\begin{tabular}{|c|c|c|c|c|c|c|c|c|}
\hline \multirow[b]{2}{*}{ 惢字 } & \multirow[b]{2}{*}{ 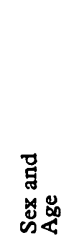 } & \multirow[b]{2}{*}{ 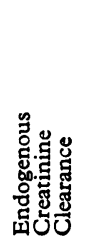 } & \multirow[b]{2}{*}{ 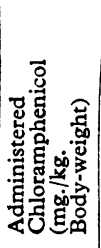 } & \multicolumn{2}{|c|}{$\begin{array}{l}\text { Serum ( } \mu \text { g. Chlor- } \\
\text { amphenicol } / \mathrm{ml} \text {.) }\end{array}$} & \multicolumn{2}{|c|}{ Urine } & \multirow[b]{2}{*}{ 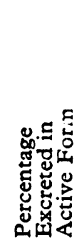 } \\
\hline & & & & & & 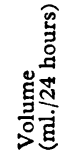 & 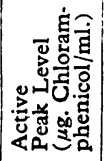 & \\
\hline $\begin{array}{c}1 \\
2 \\
3 \\
4 \\
5 \\
6 \\
7 \\
8 \\
99 \\
10 \\
11 \\
12 \\
13 \\
14 \\
15 \\
116 \\
17 \\
18 \\
19 \\
21 \\
22 \\
23 \\
24 \\
25 \\
27 \\
28 \\
29 \\
30\end{array}$ & $\begin{array}{|ll|}M & 33 \\
M & 55 \\
M & 20 \\
M & 47 \\
M & 59 \\
\mathrm{~F} & 15 \\
M & 45 \\
\mathrm{~F} & 45 \\
M & 52 \\
M & 73 \\
\mathrm{~F} & 65 \\
M & 42 \\
\mathrm{~F} & 68 \\
\mathrm{~F} & 73 \\
M & 20 \\
M & 49 \\
\mathrm{~F} & 16 \\
\mathrm{~F} & 57 \\
M & 54 \\
M & 47 \\
M & 49 \\
M & 61 \\
M & 20 \\
F & 48 \\
F & 19 \\
F & 59 \\
\mathrm{~F} & 67 \\
\mathrm{~F} & 74 \\
\mathrm{~F} & 82 \\
\mathrm{~F} & 62 \\
\mathrm{~F} & 69\end{array}$ & $\begin{array}{r}120 \\
100 \\
95 \\
88 \\
64 \\
60 \\
57 \\
43 \\
38 \\
38 \\
34 \\
21 \\
12 \\
9 \\
8 \\
8 \\
7 \\
7 \\
5 \\
2 \\
120 \\
100 \\
97 \\
79 \\
78 \\
76 \\
59 \\
37 \\
33 \\
33 \\
23\end{array}$ & $\begin{array}{l}2 \\
13 \\
19 \\
11 \\
23 \\
52 \\
16 \\
20 \\
40 \\
38 \\
19 \\
29 \\
15 \\
19 \\
16 \\
30 \\
21 \\
39 \\
30 \\
29 \\
46 \\
16 \\
18 \\
50 \\
20 \\
48 \\
16 \\
15 \\
40 \\
13 \\
26\end{array}$ & $\begin{array}{r}30 \\
6 \\
\\
8 \\
18 \\
6 \\
14 \\
9 \\
12 \\
16 \\
23 \\
6 \\
11 \\
7 \\
16 \\
12 \\
10 \\
14 \\
16\end{array}$ & $\begin{array}{r}45 \\
10 \\
- \\
22 \\
35 \\
13 \\
22 \\
36 \\
70 \\
24 \\
52 \\
19 \\
33 \\
82 \\
115 \\
107 \\
65 \\
80\end{array}$ & $\begin{array}{l}4,000 \\
970 \\
1,780 \\
1,630 \\
2,360 \\
1,290 \\
2,265 \\
1,010 \\
1,600 \\
1,995 \\
1,750 \\
2,445 \\
3,200 \\
1,215 \\
1,975 \\
1,380 \\
1,740 \\
2,540 \\
1,560 \\
430 \\
3,840 \\
1,700 \\
1,500 \\
1,500 \\
1,350 \\
3,780 \\
1,100 \\
1,870 \\
1,900 \\
1,680 \\
1,300\end{array}$ & $\begin{array}{r}160 \\
180 \\
154 \\
77 \\
80 \\
114 \\
38 \\
102 \\
160 \\
80 \\
96 \\
90 \\
7 \\
51 \\
14 \\
16 \\
18 \\
8 \\
14 \\
8\end{array}$ & $\begin{array}{c}13.5 \\
4.1 \\
8.9 \\
5.3 \\
5.5 \\
3.3 \\
1.3 \\
3.4 .3 .6 \\
0.4 \\
1.3 \\
3.3 \\
3.4 \\
0.6 \\
0.8 \\
1.0 \\
0.3 \\
0.7 \\
0.3 \\
0.6 \\
0.1 \\
6.7 \\
3.7 \\
6.7 \\
4.6 \\
6.1 \\
4.2 \\
1.5 \\
2.7 \\
1.4 .1 .6 \\
2.5 \\
0.5,1.0\end{array}$ \\
\hline
\end{tabular}

\section{Material and Methods}

The material consisted of 31 patients (see Table) in the medical ward of St. Eriks Sjukhus, Stockholm. They were chosen as representing various degrees of impairment of the renal function. Twenty were given a single dose of 1,2 , or $3 \mathrm{~g}$. of chloramphenicol orally; 11 were given continuous therapy with a total daily dose of 1.5 to $3 \mathrm{~g}$. of chloramphenicol.

Blood and urine were sampled at fixed intervals. In the patients who received the single dose such samples were taken every other hour during the first eight hours, and after this at longer intervals. Serum and urine were stored at $-20^{\circ} \mathrm{C}$. until the concentration tests were carried out.

The concentration of active chloramphenicol in the serum and urine was determined by means of the tube dilution method: $0.5 \mathrm{ml}$. of a $10^{-4}$ dilution of an 18-hour culture of a Klebsiella pneumoniae strain $^{1}$ inhibited by $0.6 \mu \mathrm{g}$. (minimal inhibitory concentration) of chloramphenicol per ml. was added to $1 \mathrm{ml}$. of serum or urine diluted in twofold steps. The tubes were incubated at $37^{\circ} \mathrm{C}$., read after 18 hours, shaken, and then re-read after 24 hours. The lowest serum or urine dilution giving inhibition of bacterial growth was taken as the concentration value of chloramphenicol. The sensitivity of the Klebsiella strain to chloramphenicol was checked each time.

The chemical method employed for determining chloramphenicol in the serum and urine was a modification of the method described by Bessman and Stevens (1950). The nitrobenzol group was reduced with tin chloride, and the resulting aromatic amino-compound was diazotized and the colour read at $550 \mathrm{~m} \mu$ in a spectrophotometer. By this method total chloramphenicol-i.e., active compound plus its metabolites-was determined. ${ }^{2}$

\section{Concentration of Active Chloramphenicol and Its Metabolites in the Blood}

Fig. 1 shows the concentration of active chloramphenicol as well as the concentration of total chloramphenicol in the blood. The material of patients was divided into three groups according to the state of renal function: group 1, with an endogenous creatinine clearance of $61-120 \mathrm{ml}$./minute ; group 2, with a clearance of 20-60 ml./minute; and group 3, with clearance values of less than $20 \mathrm{ml}$./minute.

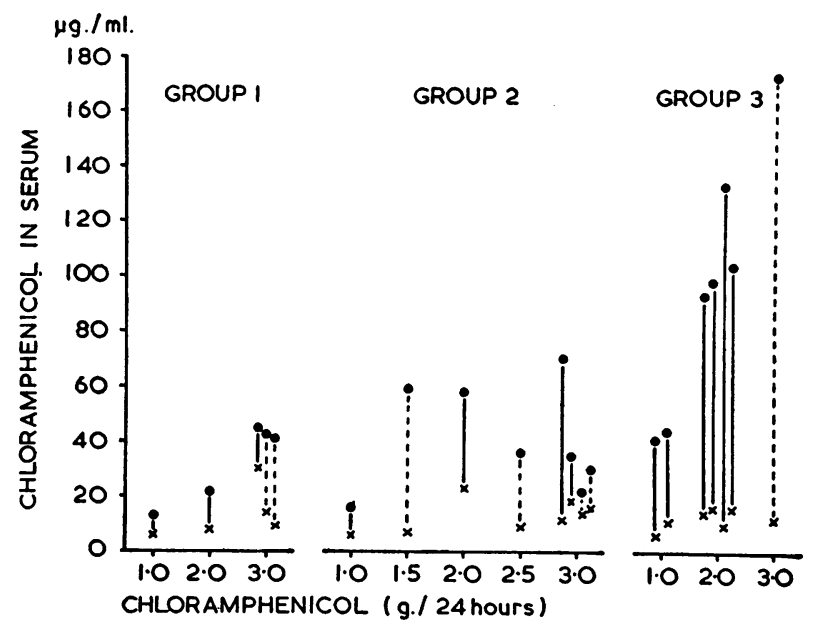

FIG. 1.-Serum concentration of total and biologically active chloramphenicol at different levels of renal function. $x=$ Concentration of active chloramphenicol in serum. $=$ Concentration of total chloram-
phenicol in serum. phenicol in serum. dose during continuous therapy.

In the four patients who received $1 \mathrm{~g}$. of chloramphenicol the mean of the maximal concentration of active chloramphenicol in the serum was $7 \mu \mathrm{g} . / \mathrm{ml}$. (range $6-11 \mu \mathrm{g}$.); in the six patients given $2 \mathrm{~g}$. the mean was $15 \mu \mathrm{g}$. $(8-23 \mu \mathrm{g}$.) ; and in the three given $3 \mathrm{~g}$. the mean was $20 \mu \mathrm{g}$. (12-30 $\mu \mathrm{g})$.

\footnotetext{
'Kindly supplied by Dr. G. Tunevall, Sjukvårdsstyrelsens Bakt. Lab., Stockholm.

${ }^{2}$ The chemical modification was elaborated by Dr. Ake Holmgård, Klin. Centrallab., St. Eriks Sjukhus, Stockholm.
} 
After 24 hours no active chloramphenicol could be demonstrated in the blood of any patient. On comparing the patients in the three renal-function groups, no clear difference was found in the levels of active chloramphenicol in the serum.

Five patients were given continuous therapy with $1 \mathrm{~g}$. of chloramphenicol three times a day. A maximum concentration of active chloramphenicol in the blood, $14 \mu \mathrm{g} . / \mathrm{ml}$. (12-16 $\mu \mathrm{g}$.), was found on the fourth day.

Four patients were given continuous therapy with daily chloramphenicol doses ranging from 1.5 to $2.5 \mathrm{~g}$. a day. Maximum concentrations fell within the limits reported above.

Our findings showed that the concentration of active chloramphenicol in the blood was little influenced by the renal function. The situation regarding the concentration of total chloramphenicol, however, was different. The patients in group 1, on single dose, attained maximum total chloramphenicol values of $13-45 \mu \mathrm{g} . / \mathrm{ml}$. ; the corresponding figures were $16-70 \mu \mathrm{g}$. for group 2 and $41-133 \mu \mathrm{g}$. for group 3 . During continuous therapy the following values were obtained: group 1, 25-43 $\mu \mathrm{g} . / \mathrm{ml}$. ; and group 2, 22-59 $\mu \mathrm{g} . / \mathrm{ml}$. In group 3 there was only one patient under continuous therapy, the maximum concentration of total chloramphenicol in this case being $173 \mu \mathrm{g}$./ $\mathrm{ml}$. There were also differences regarding the time when the maximum concentration after a single dose was reached: in group 1 after four hours, in group 2 after six hours, and in group 3 after 14 hours. Among the patients of groups 1 and 2 the metabolites had disappeared from the blood-stream within 48 hours after a single dose; in group 3 metabolites were found in the blood after this interval. Two patients with endogenous creatinine clearance values of 5 and $2 \mathrm{ml}$./minute showed metabolites in the blood after as long an interval as 7 and 10 days respectively.

\section{Concentration of Active Chloramphenicol in the Urine}

After a single oral dose of $1 \mathrm{~g}$. of chloramphenicol in patients with normal renal function (endogenous creatinine clearance greater than $100 \mathrm{ml}$./minute), maximum values of $150-180 \mu \mathrm{g} . / \mathrm{ml}$. of active chloramphenicol were reached after two to five hours. The concentration after eight hours was about $90 \mu \mathrm{g} . / \mathrm{ml}$. of urine. At lower levels of filtration the maximum values recorded fell off: in group 2 the maximum concentrations of active chloramphenicol in the urine varied from 40 to $130 \mu \mathrm{g} . / \mathrm{ml}$. The eight-hour value here was about $40 \mu \mathrm{g} . / \mathrm{ml}$.

Fig. 2 shows the concentration of active chloramphenicol in the urine of patients in group 3 compared with those in

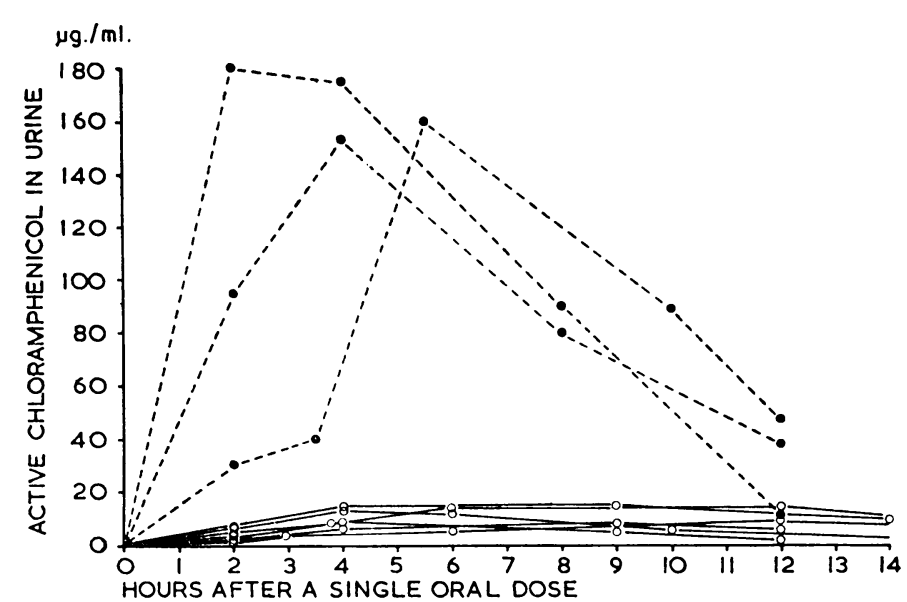

FIG. 2.-Urinary concentration of biological active chloramphenicol after a single oral dose given to patients with normal and markedly reduced renal function. 100-200 ml./minute, given $1 \mathrm{~g}$. chloramphenicol. O-O Patients with endogenous creatinine clearance less than $20 \mathrm{ml}$./minute, given 1 or $2 \mathrm{~g}$. chloramphenicol. group 1. In the four patients in group 3 given 2 g. of chloramphenicol maximum concentrations of $8-16 \mu \mathrm{g} . / \mathrm{ml}$. of urine were recorded, these values being reached after four and a half to nine hours. The concentration in the urine eight hours after administration was between 5 and $15 \mu \mathrm{g} . / \mathrm{ml}$. The two patients in group 3 given a single dose of $1 \mathrm{~g}$. had maximum values of 7 and $14 \mu \mathrm{g} . / \mathrm{ml}$. of urine, the eight-hour values here being 5 and $9 \mu \mathrm{g} . / \mathrm{ml}$. respectively. Because of impairment of the renal function, the patients in group 3 were unable to concentrate their urine, and so the concentrations of active chioramphenicol in the urine of these patients never reached a peak, and the curve obtained was relatively flat.

Only one of the patients in this group received continuous chloramphenicol therapy, $1 \mathrm{~g}$. three times a day. Here too there were low concentrations in the urine, the maximum value of active chloramphenicol, reached on the fourth day, being in this instance $22 \mu \mathrm{g} . / \mathrm{ml}$. The morning values recorded before the first administration of the day varied between 7 and 16 $\mu \mathrm{g} . / \mathrm{ml}$. of urine.

\section{Correlation Between Renal Function and Excretion of Active Chloramphenicol}

Fig. 3 shows the correlation between the patients' endogenous creatinine clearance and the percentage of administered chloramphenicol excreted in the active form. By this means the variation in maximum values could be eliminated-for example, variations arising from the varying volumes of urine obtained from the patients. In patients with a completely normal renal function-that is, with an endogenous creatinine clearance exceeding $100 \mathrm{ml} . /$ minute, the percentage of active chloramphenicol lay between 3.5 and 13, which is in agreement with published results (Ley et al., 1948 ; Glazko et al., 1949). If the renal function is only slightly impaired the percentage falls and lies, in the clearance range of $60-100 \mathrm{ml} . /$ minute, between 3.5 and 9 . The majority of older patients, with a physiologically inhibited filtration, fell into this clearance range (Davies and Shock, 1950). The patients in group 2, with a clearance range of $20-60 \mathrm{ml}$./minute, excreted between 0.4 and $3.4 \%$ of the administered dose in the active form. The patients with the most unsatisfactory glomerular filtration, group 3, excreted less than $1 \%$ in the active form. The lowest excretion was found in a patient (Case 20) (clearance $2 \mathrm{ml}$./ minute) who excreted only $0.09 \%$. The fall in the percentage

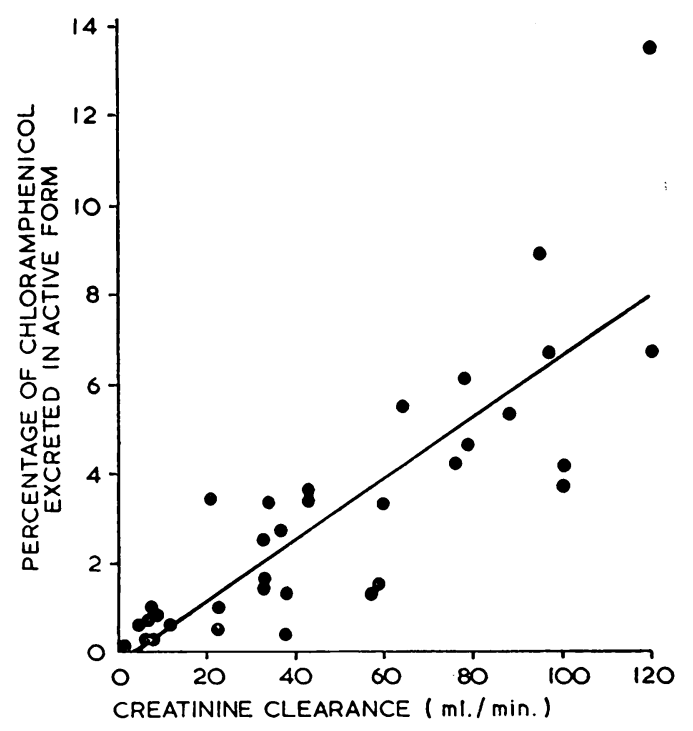

FIG. 3.- Relation between the endogenous creatinine clearance and the biological active chloramphenicol excreted in urine (percentage of administered dose). The correlation is statistically significant $(P<0.001)$, the regression line being expressed by the equation $y=0.0683 \times-0.229$. In three patients (Nos. 8, 29, and 31) the estimations were duplicated. 
excretion of chloramphenicol in the active form was directly correlated to the reduced renal function expressed as endogenous creatinine clearance.

\section{Discussion}

The therapeutic results of antibiotic administration in infections of the urinary tract vary, apart from the drug, chiefly an the composition of the patient-material and the duration of the follow-up. Provided that the bacteria in the urine are sensitive to the agents employed, a good effect is obtained initially. However, the longer the follow-up after discontinuation of the therapy the more frequent are the findings of relapse, either with the original infecting organism or with other bacteria, most often in patients with complicated or chronic disease of the kidneys or the urinary tract.

In the choice of antibiotic or chemotherapeutic agent it has often been discussed whether high concentrations in the serum and tissues or high concentrations in the urine are the most important for the treatment of urinary-tract infection. Logical reasons for the necessity of inducing inhibiting concentrations of antibiotics in the serum come readily to mind, but clinical support for this hypothesis has not been forthcoming. In their comparative studies in this field McCabe and Jackson (1965) did not find any proof for the necessity of inhibiting serum concentrations. On the other hand, they did find that inhibiting concentrations in urine were needed for satisfactory therapeutic results, even though such concentrations did not guarantee that the results would always be satisfactory. Inhibitory, usually bactericidal, concentrations in the urine were found in all patients who became free from bacteria. The view that it is necessary to have high concentrations in the urine is also supported by the fact that such agents as nitrofurantoin, which appear in the serum only at low concentrations, if at all, often have good therapeutic results. Our experience has also indicated that it is the concentrations in the urine which are the most important factors in the treatment of chronic infections of the urinary tract.

Our investigations showed that in patients with a normal renal function the maximum concentration of active chloramphenicol in the urine lay between 150 and $180 \mu \mathrm{g} . / \mathrm{ml}$. after the oral administration of $1 \mathrm{~g}$. of chloramphenicol. These values correspond with already published results (Welch and Lewis, 1951). The maximum values fall with increasing impairment of the renal function, and, as Fig. 3 shows, the excretion is linearly correlated to the glomerular filtration. The patients with an endogenous creatinine clearance value of less than $20 \mathrm{ml}$./minute showed maximum concentrations of chloramphenicol in the urine of 8-16 $\mu \mathrm{g}$./ml., with a 24-hour mean concentration of 6-7 $\mu \mathrm{g}$. In these patients, therefore, less than $1 \%$ of the dose administered was excreted in the form of active chloramphenicol.

The concentration of active chloramphenicol in the blood after a single oral dose did not give rise in our material to any obvious differences between the groups with differing renal function (Fig. 1). Similar findings were attained by Kunin et al. (1959): the serum half-life of active chloramphenicol in normal individuals was 1.6-3.5 hours, and in anuric individuals 3.2-4.3 hours.

In patients with normal renal function the metabolites disappeared from the blood-stream after 48 hours, while in the group with impaired renal function the metabolites remained for as long as 10 days. These values also correspond with the results obtained by Kunin et al. (1959); the metabolite half-life in normal individuals was $3.7-4.6$ hours, and in the anuric 68.5-154.3 hours. The retention of these chloramphenicol metabolites raises the question of whether the glucuronide may not also exercise a toxic effect on the bone-marrow. Studies on the importance of the concentration of active chloramphenicol and its metabolites in the serum, and on the renal function in cases of aplastic anaemia, have been reported on, but they do not seem to have been able to arrive at any definite conclusions (Rubin et al., 1958; McCurdy, 1963 ; Suhrland and Weisberger, 1963).

Barber and Garrod (1963) give the following average minimal inhibitory concentration values of chloramphenicol for bacteria commonly met with in infections of the urinary tract: Streptococcus faecalis, $2 \mu \mathrm{g} . / \mathrm{ml}$.; Escherichia coli, 2-8 $\mu \mathrm{g} . / \mathrm{ml}$.; Klebsiella aerogenes, $2 \mu \mathrm{g}$.-resistant ; various species of Proteus, 4-64 $\mu \mathrm{g} . / \mathrm{ml}$. ; Pseudomonas aeruginosa, resistant. Comparing the minimal inhibitory concentration values for these strains, in which a degree of sensitivity is present, against the concentrations of active chloramphenicol reached in the urine of patients with a filtration of less than $20 \mathrm{ml} . /$ minute, it is found that they are of the same magnitude. These concentrations must be regarded as being insufficient, since chloramphenicol is a bacteriostatic agent. In order to obtain therapeutic effect the aim is to reach concentrations higher than the value indicated by the minimal inhibitory concentration-5 to 10 times higher is considered desirable, which is a level that cannot be reached in patients with unsatisfactory renal function. Even in patients with creatinine clearance values of $20-60 \mathrm{ml}$./minute there is a risk that the concentration in the urine will not reach a therapeutically effective level. Since older people have a physiologically decreased filtration (Davies and Shock, 1950), the concentration of active chloramphenicol in the urine of such patients will also be low, thus increasing the risk of therapeutic failure.

A study of published reports on the treatment of infections of the urinary tract with chloramphenicol shows that the results vary considerably. Closer inspection reveals that quite naturally the unsatisfactory results usually stem from patients with chronic infections of the kidney and urinary tract, in which many instances of calculus formation and obstruction have been demonstrated. However, information on the renal function of the patients, measured, for example, as creatinine clearance, is usually not reported. A very important additional reason for the unsatisfactory therapeutic results obtained in a number of these patients may be found in a reduced renal function, and consequently a lower and therefore insufficient concentration of active chloramphenicol in the urine. In the same way our studies explain the finding of the growth of originally sensitive bacteria in the urine during therapy: either the concentration of active chloramphenicol in the urine was so low that no inhibitory effect was obtained, or a low chloramphenicol concentration might have provided a suitable medium for the development of resistance in the initially chloramphenicol-sensitive bacterial strains, resulting in the continued appearance of bacteria in the urine.

Tunevall and Frisk (1950) found wide individual variation in the excretion of chloramphenicol, a phenomenon which they considered was due to varying degrees of inactivation of chloramphenicol. These variations may be explained, at least in part, by the fact that the concentration of active chloramphenicol in the urine depends on the degree of renal function.

Chloramphenicol ought to be used only when bacterial strains with demonstrated sensitivity are present, because of the risk of side-effects. Moreover, it is our opinion that, even when there is in vitro sensitivity, chloramphenicol is of limited use in the treatment of infections of the urinary tract, chiefly because of the low percentage of the active substance excreted in the urine, and because this percentage falls considerably with impairment of the renal function. Satisfactory results from chloramphenicol therapy are therefore not to be looked for in patients with impaired renal function. On the other hand, it would be feasible to use the substance when treating patients with acute pyelonephritis-patients with a good renal function in whom the urinary-tract infection is 
caused by bacterial strains whose patterns of resistance exclude the usual primary agents-sulphanilamide, nitrofurantoin, and penicillins.

\section{Summary}

The excretion of biologically active chloramphenicol in urine diminishes linearly with decreasing renal function. When the renal function is reduced to an endogenous creatine clearance under $20 \mathrm{ml} . / \mathrm{min}$., less than $1 \%$ of the dose administered is excreted as the active compound, compared with $5-10 \%$ for normal renal function. The maximum excretion of chloramphenicol found at this degree of renal insufficiency was 10-20 $\mu \mathrm{g} . / \mathrm{ml}$. of urine, compared with $150-200 \mu \mathrm{g} . / \mathrm{ml}$. for normal renal function.

The low concentrations of urine might explain the poor correlation between chloramphenicol sensitivity tests in vitro and the results when treating infections of the urinary tract in patients with renal insufficiency. In elderly patients with a physiologically decreased renal filtration the urinary concentrations of chloramphenicol might be too low, increasing the risk for development of drug-resistant micro-organisms.

The level of biologically active chloramphenicol in blood was only slightly influenced by the renal function, while metabolites of the drug accumulated in patients with decreased renal function.
REFERENCES

Barber, M., and Garrod, L. P. (1963). Antibiotic and Chemotherapy. Livingstone, London.

Bessman, S. P., and Stevens, S. (1950). F. Lab. clin. Med., 35, 129.

Boger, W. P., Matteucci, W. V., and Beatty, J. O. (1951). Proc. Soc. exp. Biol. (N.Y.), 76, 222 .

Chittenden, G. E., Sharp, E. A., Vonder Heide, E. C., Bratton, A. C., Glazko, A. J., and Stimpert, F. D. (1949). F. Urol. (Baltimore), 62, 771 .

Davies, D. F., and Shock, N. W. (1950). F. clin. Invest., 29, 496.

Erlanson, P., and Lundgren, A. (1964). Acta med. scand., 176, 147.

Glazko, A. J., Wolf, L. M., Dill, W. A., and Bratton, A. C., jun. (1949)

7. Pharmacol. exp. Ther., 96, 445.
Hewitt, W. L., and Williams, B., jun. (1950). New Engl. F. Med., 242, 119.

Högman, C., and Tillegård, P. A. (1954). Acta chir. scand., 107, 282.

Kunin, C. M., and Finland, M. (1959). Arch. intern. Med., 104,

1030. Glazko, A. J., and Finland, M. (1959). f. clin. Invest., 38, 1498.

Ley, H. L., Smadel, J. E., and Crocker, T. T. (1948). Proc. Soc. exp. Biol. (N.Y.), 68, 9.

McCabe W: R., and Jackson, G. G. (1965). New Engl. F. Med., 272, 1037.

McCurdy, P. R. (1963). Blood, 21, 363.

Rubin, D., Weisberger, A. S.. Botti, R. E., and Storaasli, J. P. (1958). f. clin. Invest., 37, 1286.

Schück, O., Cholinský, K., Smahel, O., and Grafnetterovă, J. (1959). Antibiot. Med., 6, 98.

Suhrland, L. G., and Weisberger, A. S. (1963). Arch. intern. Med., 112,

747., G., and Frisk, A. R. (1950). Scand. F. clin. Lab. Invest., 2, 162 .

Turck, M., Browder, A. A., Lindemeyer, R. I., Brown, N. K., Anderson, K. N., and Petersdorf, R. G. (1962). New Engl. f. Med., 267, 999. N., and Petersdorf, R. G. (1962). Welch, H., and Lewis, C. N. (1951).

\title{
Studies on Debrisoquine Sulphate
}

\author{
A. H. KITCHIN, ${ }^{*}$ PH.D., M.B., M.R.C.P., F.R.C.P.ED. ; R. W. D. TURNER, † O.B.E., M.D., F.R.C.P., F.R.C.P.BD.
}

Brit. med. F., 1966, 2, 728-731

Control of the blood-pressure in hypertensive patients is now easier with drugs in current use. In the majority of patients blood-pressure can be reduced considerably, and usually, but not always, maintained at the desired level without undue sideeffects or intermittent hypotension. Consequently, with adequate drugs already available it is becoming more difficult to assess the relative merits of new preparations.

It takes at least 12 months to form a preliminary assessment of a promising new drug, and the first patients have usually been under treatment for two to three years before a confident opinion can be given on an adequate number of cases, particularly as regards tolerance.

In this country ganglion-blocking agents have been largely superseded by preparations which have no effect on the parasympathetic nervous system. At the present time most patients with severe hypertensive disease are probably being treated with the sympathetic-blocking drugs guanethidine or methyldopa, but clinical trials on new preparations are going on in many hospitals.

Patients vary in their preferences for different drugs largely owing to the varying side-effects.

Rather than carry out comparative trials or double-blind trials with different preparations in the same group, it is now sufficient to try different preparations only in those who cannot tolerate the drug with which most experience has been gained.

\footnotetext{
- Physician, Western General Hospital, Edinburgh. Senior Lecturer in Physiology, University of Edinburgh.

† Physician and Cardiologist, Western General Hospital, Edinburgh ; Reader in Medicine, University of Edinburgh.
}

With regard to the assessment of new preparations, hospitals with facilities for clinical research can usually tell from a pilot trial on an adequate number of patients whether a new preparation is likely to prove an advance and whether trials on a larger scale are warranted.

In our experience guanethidine was a distinct advance over previous preparations, but, nevertheless, tolerance in a few patients and side-effects in many necessitated the giving of adjuvants or antidotes in about half the cases. Only $60 \%$ of patients treated for more than two years maintained a good or fair result. It was concluded that, although guanethidine, particularly in combination with an oral diuretic, was better than previously available drugs for the long-term treatment of hypertension, it had a number of disadvantages (Lowther and Turner, 1963).

Methyldopa proved to be equally effective as regards reduction of blood-pressure. On the whole, side-effects were fewer and less unpleasant, but some patients were completely intolerant of side-effects; others felt generally unwell, and most experienced unpleasant symptoms in some degree (Johnson, Kitchin, Lowther and Turner, 1966).

Some patients therefore preferred methyldopa and others guanethidine, but neither preparation was entirely satisfactory. Consequently we agreed to carry out a pilot trial with a new and more promising drug with an action reputed to be similar to that of guanethidine.

Debrisoquine sulphate (Declinax) was originally synthesized in 1961 , and is a colourless, crystalline, water-soluble substance. 